\title{
Long Non-Coding RNA BLACATI Induces Tamoxifen Resistance in Human Breast Cancer by Regulating miR-503/Bcl-2 Axis [Retraction]
}

Qu R, Hu C, Tang Y, Yu Q, Shi G. Cancer Manag Res. 2020;12:1771-1777.

The Editor-in-chief and Publisher of Cancer Management and Research wish to retract the published article. Concerns were raised regarding discrepancies in the flow cytometry images used in Figures 1B, 2C and 4E. The authors did respond to our queries but were unable to provide the raw data for their flow cytometry results and could not provide raw data for other aspects of their study, including the western blots. The findings of the study could not be validated and the decision was made to retract the article. The authors agree with this decision.

Our decision-making was informed by our policy on publishing ethics and integrity and the COPE guidelines on retraction.

The retracted article will remain online to maintain the scholarly record, but it will be digitally watermarked on each page as "Retracted".

\section{Publish your work in this journal}

Cancer Management and Research is an international, peer-reviewed open access journal focusing on cancer research and the optimal use of preventative and integrated treatment interventions to achieve improved outcomes, enhanced survival and quality of life for the cancer patient.
The manuscript management system is completely online and includes a very quick and fair peer-review system, which is all easy to use. Visit http://www.dovepress.com/testimonials.php to read real quotes from published authors. 